\title{
A Limnological Assessment of Kasnazan Impoundment Water- Erbil, Iraq
}

\author{
Yadi Omer Mustafa Al-Barazingy \\ Environmental Science Department, Science College, Salahaddin \\ University- Erbil, Iraq.
}

Received
$03 / 08 / 2008$

Accepted

15 / 07 / 2009

الخالصة

مق قيم نوعية الميه مسطح كسنزان الواقعة فيشمل ششرق مدينة أربيل، اعتماداً على

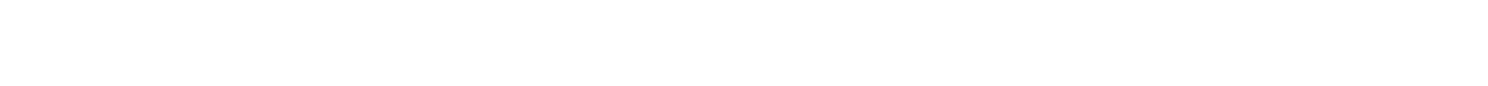

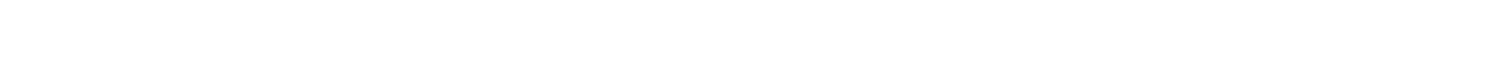

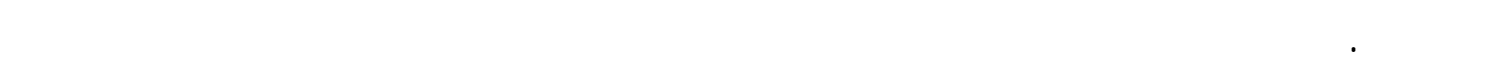
الفوسفات السليكلت وكثلفة الهائملت النباتية بين الموقع الاول وقية المواقع المدروسة، كما وجدت علاقةطردية بين تركيز صبغة كلوروفيل a وكثلفة الهائملت النباتية.

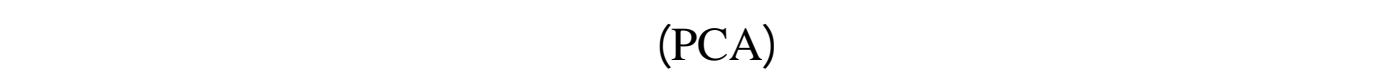
التلوث الآتية من الأسمدة الكيمياوية والمظفلت المستبلت المبنملة في المطقة.

\section{Abstract}

The assessment of physicochemical and biological conditions at five sites in Kasnazan impoundment water were conducted at monthly interval during August 2004 to February 2005, in order to know the degree of deterioration of water quality caused by anthropogenic activities in the area. Depending on statistical analysis water quality changes showed significant differences $(\mathrm{P}<0.05)$ in conductivity, $\mathrm{pH}, \mathrm{PO}_{4}, \mathrm{SiO}_{2}$ and phytoplankton density between site 1 and other studied sites. In addition to a positive relationship between chlorophyll $a$ concentration and phytoplankton density was observed.

Generally, principal component analysis (PCA) showed that water quality was impacted by fertilizer and detergents. 


\section{Introduction}

The growth and biomass of phytoplankton in reservoirs and impoundments are regulated by various physical and chemical factors (1). Those parameters, including precipitation, flow rate, concentrations of suspended solids and nutrients (2). Chlorophyll $a$ concentration in a lake is often used as an indicator of primary productivity (3). Kasnazan impoundment water is one of the largest lentic water body located in northeast of Erbil city. Morphometrically, it has a surface area of $34040.735 \mathrm{~m}^{2}$ (4). The impoundment provides Kasnazan sub district with water for drinking, irrigation, animal watering and other purposes especially during dry seasons.

In the last two decades, urbanization has led to deterioration in the water quality of impoundment through fertilizers, soil run-off and detergents. Several works which mainly concerned the physico-chemical and phytoplankton production of impoundment had been carried out $(5,6,7,8,4$, 9 and 10).

The objective of this study was to describe the water quality and rate of biological characteristic through phytoplankton densities and chlorophyll $a$ concentration in this impoundment.

\section{Materials and Methods}

Kasnazan impoundment locates (10 Km east of Erbil city, Figure 1) at an altitude of $646 \mathrm{~m}$, latitude $38{ }^{\circ} \mathrm{S} 0423768$, and longitude $40^{\circ} 07776$ $\operatorname{UTM}(4)$. Its artificial water basin instructed to collect water from the perennial Kahreez. The water is used for various purposes: drinking, domestic uses, irrigation, swimming, and recreation. Water pollutants disposed into the impoundment comes from cars washing, animal manure during watering animals and soil erosion by rainfall action.

Sampling for water quality parameters were carried out in the five studied sites at monthly intervals between August 2004 to February 2005. Water temperature was recorded with by means of thermometer, electrical conductivity with (WTW LF digi 550 conductivity meter), $\mathrm{pH}$ by using (pH meter PW 9420). The reactive orthophosphate was measured by the phosphomolybidic- ascorbic acid method, nitrate was measured by the diazotation method after reduction with $\mathrm{Cu}-\mathrm{Cd}$ column, ammonium with indophenol method and silicate by silicomolybidic- oxalic acid method (11), whereas, the chlorophyll $a$ concentration of the prepared samples were determined spectrophotometrically using the acetone extraction method (12). Phytoplankton was determined by using filtration method through $0.45 \mu \mathrm{m}$ membrane filter as described by (13). 
Physico-chemical parameters were compared using RBD ANOVA. Duncan's tests were applied to determine the differences between sampling sites in regard to estimated variables. All data were $\log _{10}(\mathrm{X}+1)$ transformed to achieve the condition of normality and homocedasticity of the data, principal component analysis (PCA) was performed to relate phytoplankton and chlorophyll $a$ variable to a biotic variables (14).

\section{Results and Discussion}

Table (1) summarizes the mean \pm SE values of the various parameters monitored at the five selected sites over seven month time span (August 2004 - February 2005) in Kasnazan impoundment water. The change in water temperature in site 1 (spring) was $1{ }^{\circ} \mathrm{C}$ during studied period. (15, 16 and 17) obtained same changes in spring water temperature and indicated that those springs as thermostatic types. Meanwhile, wide variation in water temperature was recorded in other sites (reached to more than $21^{\circ} \mathrm{C}$ ), with no statistically significant differences $(\mathrm{P}<0.05)$ between studied sites, this may be due to the shallowness of impoundment water (18). (4, 5 and 8) found the same results in previous studies on Kasnazan water impoundment. Mean surface water electrical conductivity value was $606.5 \mu \mathrm{s} . \mathrm{cm}^{-1}$ in site 1 with decreases in its values towards other sites; this phenomenon was observed by (7), who returns the reasons to the source of water and the effect of precipitation. Meanwhile, significant differences in $\mathrm{pH}$ value (as mean) were observed from spring source (site 1) to other sites. (15) reported that there is a gradually rise in $\mathrm{pH}$ passing downstream from the spring source at Serchinar. A similar result was obtained by (19 and 20) during their studies on springs in Harier sub district. On the other hand, low phytoplankton densities and chlorophyll $a$ concentration in site 1 may be one of these reasons which cause low $\mathrm{pH}$ value at this site in comparison to other sites (21).

As shown in Figure (2), the highest mean values for orthophosphate, ammonium and nitrate were recorded in site 1 with gradually decreases towards site 4 then increased in site 5 which was coincided with inverse trend of oscillation for biological parameters in site 1 and other sites as observed in Figure (2). (22 and 23) reported that inverse pattern of oscillation noticed between nutrients concentrations and phytoplankton density. On the other hand, similar pattern of variations was noticed between phytoplankton density and chlorophyll $a$ concentration (Figure 3), this relationship was mentioned by other investigator(3).

Physico- chemical and biological variables of Kasnazan impoundment water are shown in Table (2). The first two components of PCA accounted 
as $42.4 \%$ and $15.4 \%$ of variance explained respectively, which characterized by positive contribution for $\left(\mathrm{SiO}_{2}, \mathrm{PO}_{4}, \mathrm{NH}_{4}\right.$ and $\left.\mathrm{NO}_{3}\right)$ and it's related to fertilizers and detergents inputs into water by anthropogenic activities (Figure, 4). (14) found that these variables can be used as indicators of sewagewater and land application discharges. Whereas, negative contribution was observed for electrical conductivity values and this may be related to precipitation effect through slow flow rate of water in impoundment (18). As well as, third component has $15.19 \%$ of total explained variance (Figure 5), chlorophyll $a$ and $\mathrm{pH}$ values have positive contribution, while nitrate has negative contribution. (21) mentioned that photosynthesis leads to decreasing in nutrient concentrations and increased in $\mathrm{pH}$ value.

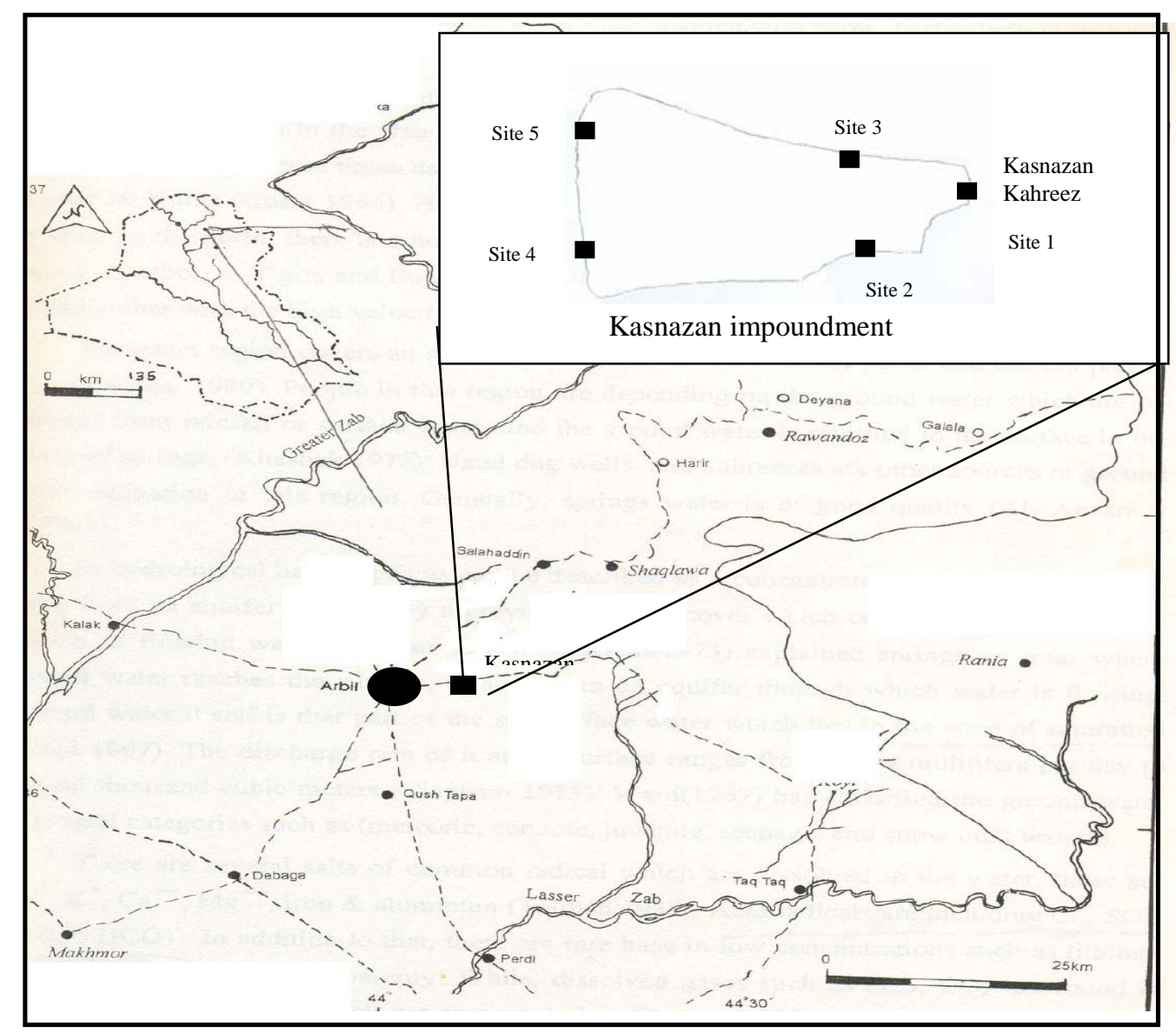

Figure (1): Show Erbil province and location of Kasnazan impoundment. 
Table (1): Physical-chemical properties of Kasnazan impoundment water, data represented as mean $\pm \mathrm{SE}$, with minimum and maximum value during studied period.

\begin{tabular}{|c|c|c|c|c|c|}
\hline Sites & 1 & 2 & 3 & 4 & 5 \\
\hline $\begin{array}{c}\text { Water } \\
\text { temperature }\left({ }^{\circ} \mathrm{C}\right)\end{array}$ & $\begin{array}{c}18.35 \pm 1.36^{a} \\
18.0-19.0\end{array}$ & $\begin{array}{c}15.78 \pm 1.36^{a} \\
7.5-29.0\end{array}$ & $\begin{array}{c}16.14 \pm 1.36^{a} \\
8.0-29.0\end{array}$ & $\begin{array}{c}15.78 \pm 1.36^{a} \\
7.0-29.0\end{array}$ & $\begin{array}{c}15.92 \pm 1.36^{a} \\
7.5-29.0\end{array}$ \\
\hline $\begin{array}{c}\mathrm{EC}\left(\mu \mathrm{S} . \mathrm{cm}^{-1}\right) \\
\left(\text { at } 25^{\circ} \mathrm{C}\right)\end{array}$ & $\begin{array}{c}606.5 \pm 14.17^{a} \\
419.4-784.7\end{array}$ & $\begin{array}{c}450.6 \pm 14.17^{b} \\
253.8-651.7\end{array}$ & $\begin{array}{c}458.5 \pm 14.17^{b} \\
253.8-665.0\end{array}$ & $\begin{array}{c}444.0 \pm 14.17^{b} \\
244.4-645.0\end{array}$ & $\begin{array}{c}452.3 \pm 14.17^{b} \\
253.8-665.0\end{array}$ \\
\hline pH & $\begin{array}{c}7.51 \pm 0.082^{a} \\
7.3-7.9\end{array}$ & $\begin{array}{c}7.85 \pm 0.082^{b} \\
6.9-8.2\end{array}$ & $\begin{array}{c}7.80 \pm 0.082^{b} \\
6.7-8.1\end{array}$ & $\begin{array}{c}7.90 \pm 0.082^{b} \\
7.2-8.2\end{array}$ & $\begin{array}{c}7.87 \pm 0.082^{b} \\
7.3-8.2\end{array}$ \\
\hline $\mathrm{NH}_{4}\left(\mu \mathrm{g} \mathrm{NH}_{4}-\mathrm{N}^{-\mathrm{I}^{-1}}\right)$ & $\begin{array}{c}4.91 \pm 0.64^{a} \\
2.05-8.91\end{array}$ & $\begin{array}{c}4.49 \pm 0.64^{a} \\
1.18-7.81\end{array}$ & $\begin{array}{c}4.87 \pm 0.64^{a} \\
0.39-10.0\end{array}$ & $\begin{array}{c}4.12 \pm 0.64^{a} \\
0.63-6.70\end{array}$ & $\begin{array}{c}4.86 \pm 0.64^{a} \\
0.94-10.42\end{array}$ \\
\hline $\mathrm{NO}_{3}\left(\mu \mathrm{g} \mathrm{NO}-\mathrm{N}_{3} \mathrm{I}^{-1}\right)$ & $\begin{array}{c}18.7 \pm 2.60 \\
7.0-33.0\end{array}$ & $\begin{array}{c}10.7 \pm 2.60^{a} \\
6.0-21.0\end{array}$ & $\begin{array}{c}17.8 \pm 2.60^{a} \\
9.0-41.0\end{array}$ & $\begin{array}{c}11.2 \pm 2.60^{a} \\
7.0-19.0\end{array}$ & $\begin{array}{c}12.97 \pm 2.60^{a} \\
8.0-22.0\end{array}$ \\
\hline $\mathrm{PO}_{4}\left(\mu \mathrm{g} \mathrm{PO}_{4}-{\mathrm{P} . \mathrm{I}^{-1}}^{-1}\right)$ & $\begin{array}{c}27.0 \pm 2.03 \\
0.47-59.1\end{array}$ & $\begin{array}{c}15.5 \pm 2.03 \\
0.84-39.1\end{array}$ & $\begin{array}{c}15.4 \pm 2.03 \\
0-45.05\end{array}$ & $\begin{array}{c}15.1 \pm 2.03 \\
0-41.69\end{array}$ & $\begin{array}{c}12.9 \pm 2.03 \\
0-35.89\end{array}$ \\
\hline $\mathrm{SiO}_{2}\left(\mu \mathrm{g} \mathrm{SiO}{ }_{2}-\mathrm{Si} \mathrm{I}^{-1}\right)$ & $\begin{array}{l}175 \pm 16.2^{a} \\
7.50-371.4\end{array}$ & $\begin{array}{l}70.4 \pm 16.2^{b} \\
10.5-178.3\end{array}$ & $\begin{array}{c}69.4 \pm 16.2^{b} \\
10.6-159.6\end{array}$ & $\begin{array}{l}58.1 \pm 16.2^{b} \\
5.59-154.1\end{array}$ & $\begin{array}{c}65.0 \pm 16.2^{b} \\
10.19-162.7\end{array}$ \\
\hline $\begin{array}{c}\text { Chlorophyll } a \\
\left(\left(\mu \mathrm{g} . \mathrm{l}^{-1}\right)\right.\end{array}$ & $\begin{array}{l}9.52 \pm 12.3^{a} \\
0.33-41.13\end{array}$ & $\begin{array}{c}23.9 \pm 12.3^{a b} \\
0.35-74.8\end{array}$ & $\begin{array}{c}20.2 \pm 12.3^{a b} \\
1.3-58.0\end{array}$ & $\begin{array}{c}16.9 \pm 12.3^{a b} \\
2.05-49.9\end{array}$ & $\begin{array}{l}52.7 \pm 12.3^{b} \\
1.02-191.7\end{array}$ \\
\hline $\begin{array}{c}\text { Phytoplankton } \\
\text { density (Cells. }^{-1} \text { ) }\end{array}$ & $\begin{array}{c}290.9 \pm 79.2^{a} \\
71.1-1157.2\end{array}$ & $\begin{array}{l}28502 \pm 79.2 \\
301.2-111585\end{array}$ & $\begin{array}{c}18069 \pm 79.2^{a b} \\
502.3-43566\end{array}$ & $\begin{array}{c}28876 \pm 79.2 \\
325-57287\end{array}$ & $\begin{array}{l}24251 \pm 79.2^{a b} \\
398.6-102556\end{array}$ \\
\hline
\end{tabular}


A Limnological Assessment of Kasnazan Impoundment Water- Erbil, Iraq.

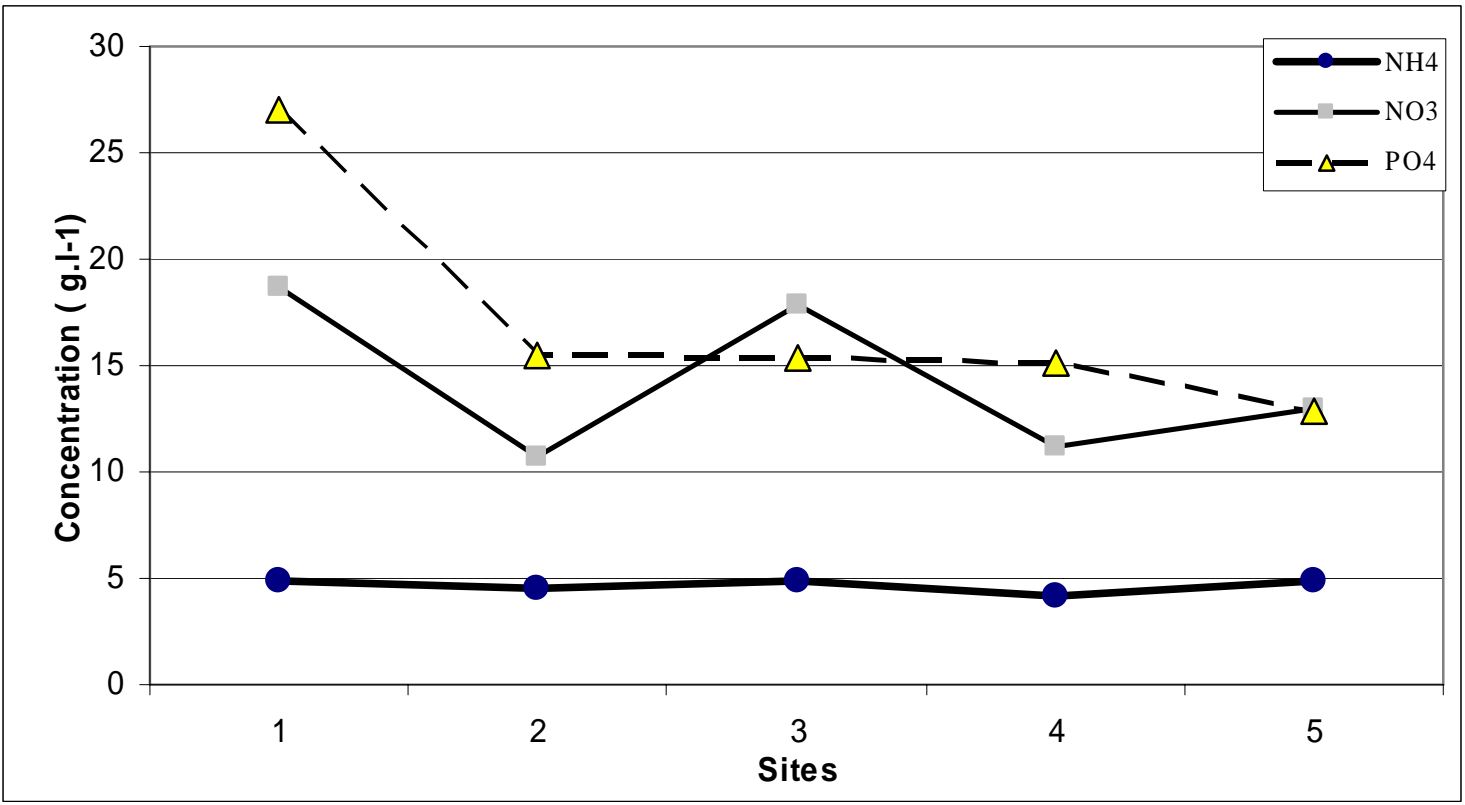

Figure (2): Nutrients concentrations ( $\left.\mu \mathrm{g} . \mathrm{I}^{-1}\right)$ variation in Kasnazan impoundment water studied sites (data represented as mean values).

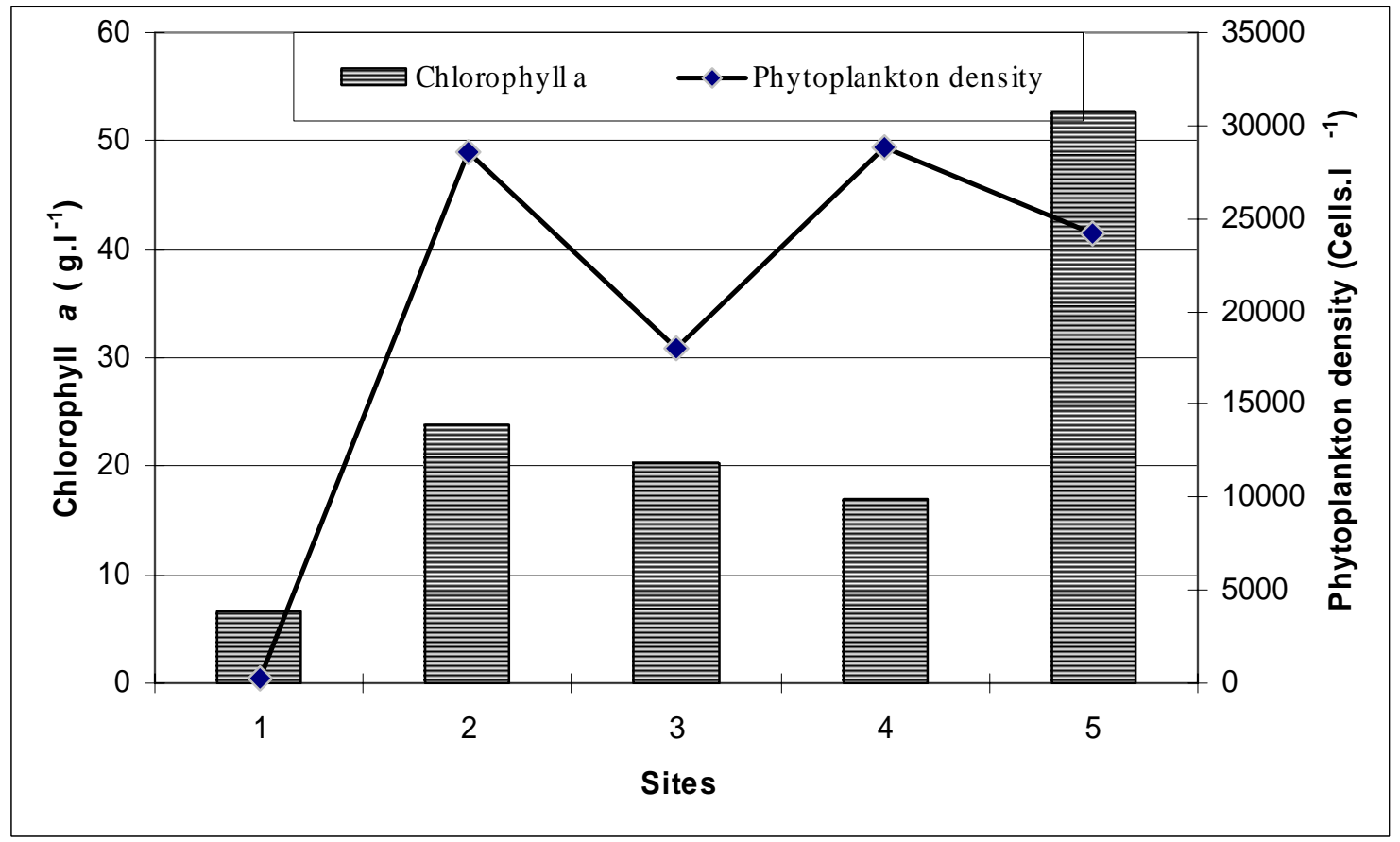

Figure (3): Variations between chlorophyll a concentration $\left(\mu \mathrm{g} . \mathrm{l}^{-1}\right.$ ) and phytoplankton density $\left(\right.$ Cells. $\left.^{-1}\right)$ in Kasnazan impoundment water. 
Table (2): Eigenvalue and percentage of variance explained by each of the six principal components (PCs) for Kasnazan impoundment water studied variables.

\begin{tabular}{|c|c|c|c|}
\hline Principal Component & $\mathbf{P C}_{1}$ & $\mathrm{PC}_{2}$ & $\overline{P \mathrm{PC}_{3}}$ \\
\hline Eigenvalue & 3.81 & 1.39 & 1.36 \\
\hline \% total variance explained & 42.42 & 15.48 & 15.19 \\
\hline \% cumulative variance & 42.42 & 57.9 & 73.09 \\
\hline \multicolumn{4}{|c|}{ Rotated factor correlation coeficients } \\
\hline Temperature & 0.397 & 0.803 & -0.297 \\
\hline Electrical conductivity & -0.450 & -0.714 & -0.356 \\
\hline pH & -0.070 & -0.317 & 0.689 \\
\hline $\mathrm{NH}_{4}$ & 0.680 & 0.462 & -0.185 \\
\hline $\mathrm{NO}_{3}$ & 0.492 & -0.120 & -0.341 \\
\hline $\mathrm{PO}_{4}$ & 0.860 & 0.315 & 0.045 \\
\hline $\mathrm{SiO}_{2}$ & 0.922 & 0.072 & 0.038 \\
\hline Chlorophyll $a$ & -0.021 & 0.095 & 0.762 \\
\hline Phytoplankton density & -0.057 & 0.945 & -0.051 \\
\hline
\end{tabular}

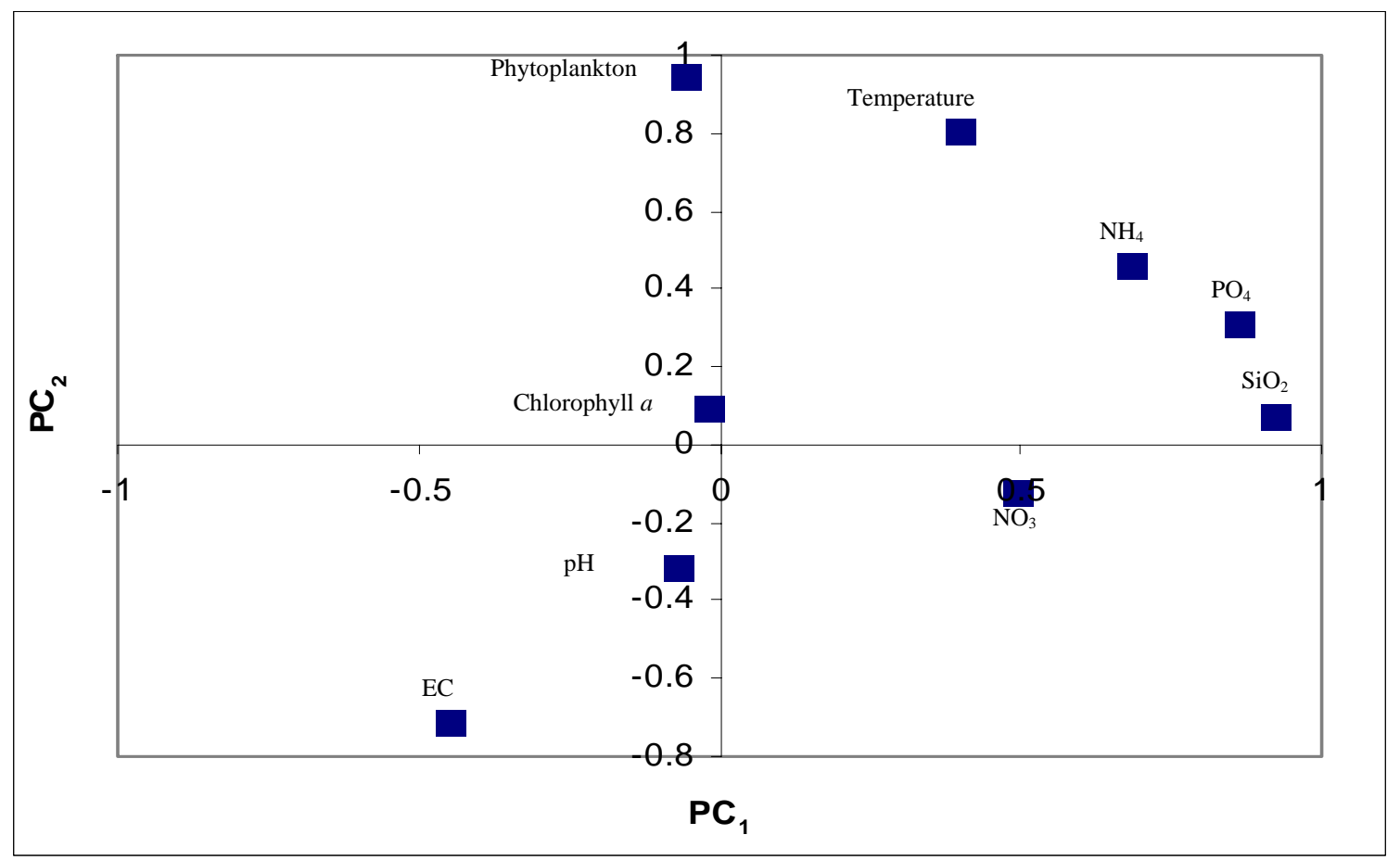

Figure (4): Principal component analysis (PCA) scatter plot of Kasnazan impoundment samples on the basis of studied water variable characteristics. 


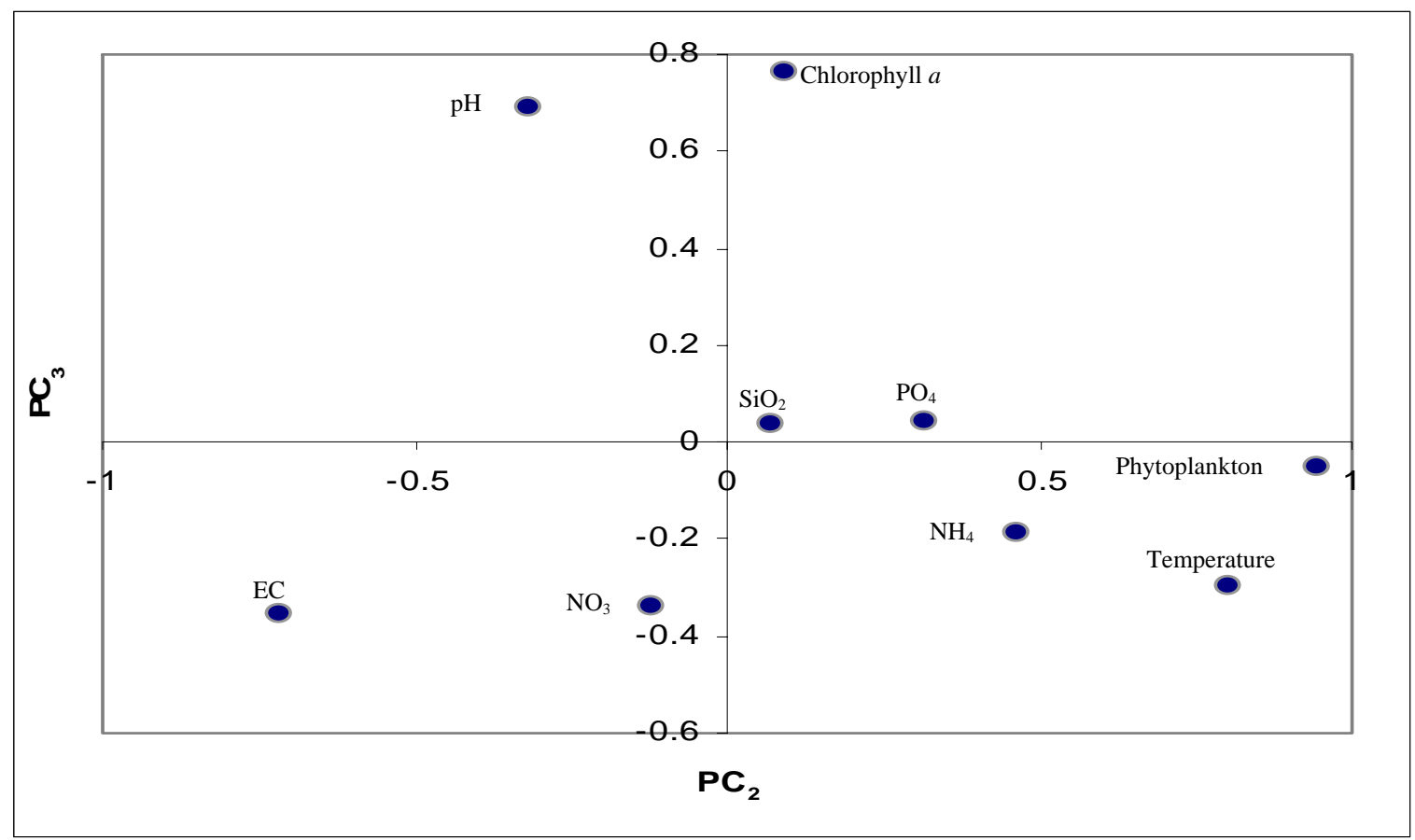

Figure (5): Principal component analysis (PCA) scatter plot of Kasnazan impoundment samples on the basis of studied water variable characteristics.

\section{References}

1) Albay, M. and Akcaalan, R., Hydrologia. 502: 85- 95. (2003).

2) Wetzel, R. G. Limnology. W. B. Saunders Company. (1975).

3) Bailey, M. and Davignon, T., UNH Center for Freshwater Biol. Res., 1(2): 13-22. (1999).

4) Goran, S. M. A., M.Sc. Thesis. Univ. of Salahaddin -Erbil. Iraq. (2006).

5) Rasheed, R. O., M.Sc. Thesis. Univ. of Salahaddin-Erbil, Iraq. (1994).

6) Al-Barzingy, Y. O. M., M.Sc. Thesis. Univ. of Salahaddin-Erbil. Iraq. (1995).

7) Toma, J. J., J. of Babylon University. (2004).

8) Bapeer, U. H. K., Ph.D. Thesis. Univ. of Salahaddin-Erbil, Iraq. (2004).

9) Esmail, A. O.; Maulood, P. M. and Shekha, Y. A. The $1^{\text {st }}$ Conference of Biology (Sept. 2007). J. Educ. and Sci. of Mosul Univ., 20(2):47- 55. (2007). 
10) Maulood, P. M., Mesoptomia J. of Agriculture. 36(20):12- 19. (2008).

11) American Public Health association (A.P.H.A.). Standard methods for the examination of water and wastewater. $20^{\text {th }}$.Ed. A.P.H.A., 1015 Fifteenth Street, NW, Washington, DC. 20005-2605. (1998).

12) Bartram, J. and Balance, R. Water quality monitoring (a practical guide to the design and implementation of freshwater quality studies and monitoring programmes). United Nation Environmental ProgrammeUNEP- and WHO. E \& FN Spon, Chapman and Hall. UK. 383pp. (1996).

13) Mcnabb, D. C., Limnological and Oceanography. 5:57- 61. (1960).

14) Ouyang, Y.; Nkedi-Kizza, P.; Wu, Q. T.; Shinde, D. and Huang, C.H. Water Res., 40:3800- 3810. (2006).

15) Maulood, B. K. and Hinton, G. C. F. Zanco J. 4:93- 117. (1978).

16) Al- Shahawani, S. M. H. M.Sc.Thesis. Univ. of Sulaimaniyah. Iraq. (1980).

17) Ibrahim, A. M. K. M.Sc.Thesis. Univ. of Salahaddin-Erbil, Iraq. (1981).

18) Schwartz, L. N. and Gruendling, G. K., J. Freshwater Ecol., 3(2):35- 45. (1985).

19) Bilbas, A. H. A. M.Sc.Thesis. Univ. of Salahaddin-Erbil, Iraq. (2004).

20) Abdulwahid, S. J. M.Sc.Thesis. Univ. of Salahaddin-Erbil, Iraq. (2008).

21) Rakocevic- Nedovic, J. and Hollert, H., Environ. Sci. and Pollut. Res. 12(3): 146- 152. (2005).

22) Henry, R.; Nogueira, M. G.; Pompeo, M. L. M. and Moschini- Carlos, V., Braz. J. Biol., 66(1B):239- 261. (2006).

23) Peterson, T. D.; Toews, H. N. J. ; Robinson, C. L. K. and Harrison, P. J., J. of Plankton Res. 29(3): 219- 239. (2007). 